\title{
Одночасна корекція коарктації аорти і двостулкового аортального клапана у дорослого пацієнта (клінічний випадок)
}

\author{
Варбанець С. В., Пукас О. Ю., Фурман М. М. \\ ДУ «Науково-практичний медичний центр дитячої кардіології та кардіохірургії МОЗ України» (Київ)
}

\begin{abstract}
Коарктація аорти є однією з найчастіших вроджених вад серця і становить 6-7\%. Коарктація аорти часто поєднана з іншими вадами серця - двостулковим аортальним клапаном, дефектом міжшлуночкової перегородки та ін.
\end{abstract}

Мета роботи - висвітлити наш перший досвід одноетапної хірургічної корекції коарктації аорти і патології аортального клапана.

Матеріали і методи. Чоловік, 56 років, поступив у відділення в плановому порядку із симптомами хронічної серцевої недостатності. Основними скаргами на момент госпіталізації були задишка при мінімальному фізичному навантаженні та підвищення артеріального тиску. Коарктація аорти була встановлена випадково, в ході проведення коронаровентрикулографії в іншому лікувальному закладі.

Результати та обговорення. Незважаючи на велику кількість публікацій у закордонних джерелах, при огляді вітчизняної літератури не було знайдено жодного описаного випадку екстраанатомічного шунтування коарктації аорти з одночасною корекцією серцевої патології у дорослого пацієнта в Україні. Згідно із досвідом іноземних фахівців, наш пацієнт мав протипоказання до екстраанатомічного анастомозу із серединної стернотомії у зв'язку зі своєю конституційною особливістю - бочкоподібною грудною кліткою. Однак використання міні-інвазивного інструментарію дало можливість успішно виконати операцію і скоротити тривалість формування дистального анастомозу.

Висновки. Екстраанатомічне формування анастомозу при коарктації аорти в комплексі із серцевою патологією є хорошим альтернативним методом лікування для дорослої когорти пацієнтів.

Ключові слова: коарктація аорти, екстраанатомічний графт, методи хірургічної корекції.

Коарктація аорти є однією з найчастіших вроджених вад серця і складає 6-7\%. Коарктація аорти часто поєднана з іншими вадами серця - двостулковим аортальним клапаном, дефектом міжшлуночкової перегородки та ін. [1]. Ця патологія може не маніфестувати впродовж тривалого періоду і бути випадковою знахідкою при діагностуванні з приводу інших причин. Наслідком захворювання є розвиток вираженої артеріальної гіпертензії, серцевої недостатності.

Мета роботи - висвітлити наш перший досвід одноетапної хірургічної корекції коарктації аорти і патології аортального клапана.

Матеріали і методи. Пацієнт, 56 років, поступив у відділення в плановому порядку із симптомами хронічної серцевої недостатності. Основними скаргами на момент госпіталізації були задишка при мінімальному фізичному навантаженні та підвищення артеріального тиску. 3 анамнезу життя відомо, що у 2012 р. i 2015 р. хворий переніс інсульт за ішемічним типом. Також пацієнт мав конституційну особливість у вигляді бочкоподібної грудної клітки. Коарктація аорти була встановлена випадково, в ході проведення коронаровентрикулографії в іншому лікувальному закла- ді. За даними ехокардіограми мала місце комбінована аортальна вада з перевагою критичного стенозу (середній градієнт 49 мм рт. ст., площа відкриття аортального клапана 0,4 см²) при наявності невеликої недостатності. Концентрична гіпертрофія стінок лівого шлуночка, товщина задньої стінки лівого шлуночка в діастолу 15 мм. Фракція викиду складала 43\%. Коронарографія: гемодиномічно значущих уражень коронарних артерій не виявлено. За даними КТ-ангіографії грудного відділу аорти з внутрішньовенним контрастуванням діагностовано різке звуження аорти в типовому місці (гемодинамічний перерив, рис. 2, 3). Множинні колатеральні судини, що впадають у низхідну аорту, максимальний діаметр до 0,9 см (рис. 1). Множинні колатеральні артерії в середостінні, передній грудній стінці, паховій ділянці та на спині (рис. 1). Виражений кальциноз аортального клапана.

Після серединної стернотомії і розрізу перикарда було підключено апарат штучного кровообігу. Канюляція аорти проксимальніше місця відходження плечоголовного стовбура, канюляція порожнистих вен типова. Загальна гіпотермія до $26^{\circ} \mathrm{C}$. На паралельній перфузії виконано ретроперикардіальний 


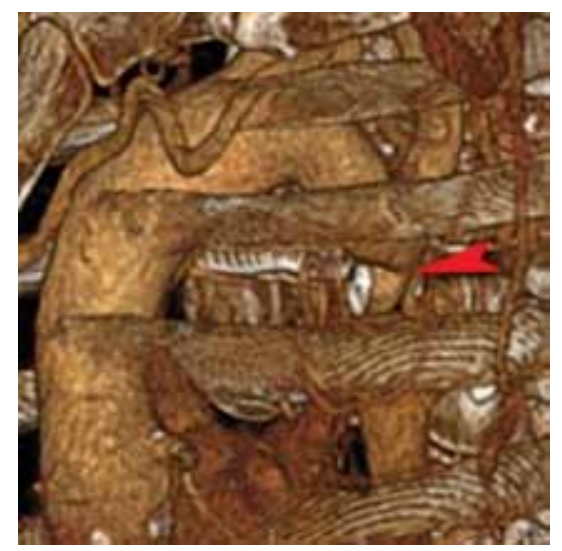

Рис. 1. КТ-ангіограма

з внутрішньовенним

контрастуванням чітко вказує на коарктацію аорти в типовому місці (вказано червоною стрілкою)

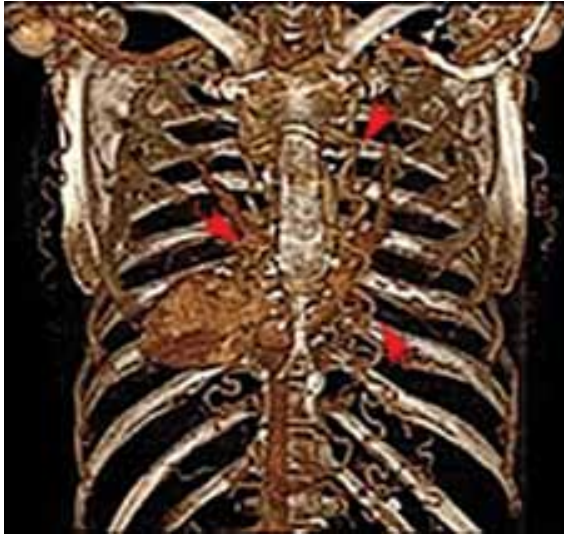

Рис. 2. КТ-ангіограма 3 внутрішньовенним контрастуванням зображує велику кількість колатералей (вказані червоними стрілками)

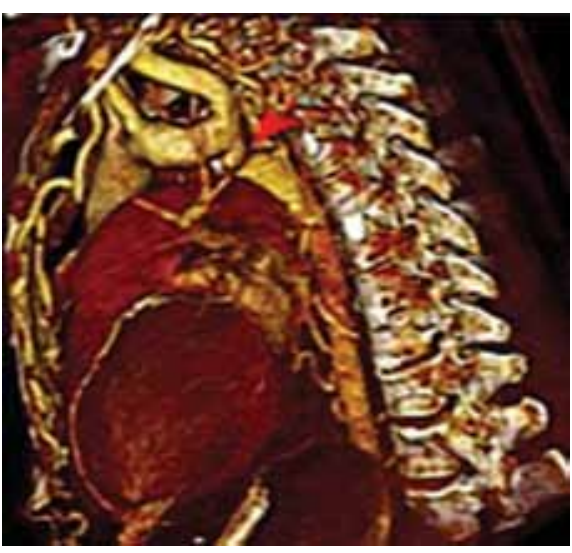

Рис. 3. КТ-ангіограма 3 внутрішньовенним контрастуванням чітко зображує коарктацію аорти у типовому місці (вказано червоною стрілкою) доступ одразу латеральніше від стравоходу і сформовано анастомоз між судинним графтом (Dacron $20 \mathrm{~mm})$ і низхідною аортою за типом «кінець у бік» із допомогою міні-інвазивного інструмента - довгого голкотримача і пінцета (Azemus). Це дало нам можливість виконати дистальний анастомоз, незважаючи на анатомічні особливості пацієнта, і скоротити тривалість операції. Кондуїт проведено позаду нижньої порожнистої вени, вздовж латерального краю серця (рис. 4, 6). Після виконання поперечної аортотомії антеградно, а в подальшому антеретроградно подавалася холодна кров'яна кардіоплегія. Анатомія аортального клапана: двостулковий, tyре I $(\mathrm{R} / \mathrm{N})$. Виконано протезування аортального клапана механічним протезом (SJM Master 23). Аорта ушита дворядним безперервним швом. Профілактика повітряної емболії, знято затискач з аорти. На паралель- ній перфузії з використанням бокового затискача сформовано проксимальний анастомоз між судинним графтом і висхідною аортою (рис. 5). Інтраопераційно контроль прямого артеріального тиску оцінювався з допомогою двох артеріальних ліній у лівій променевій артерії і лівій тильній артерії стопи. Також встановлено назогастральний зонд №20 доопераційно для полегшення верифікації та уникнення травми стравоходу під час операції. Тривалість штучного кровообігу становила 306 хвилин, тривалість перетискання аорти -115 хвилин. Хворий екстубований через 33 години після закінчення операції. Градієнт гомілково-плечового тиску значно покращився (пе-

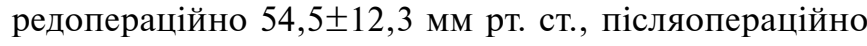
$21,2 \pm 5,1$ мм рт. ст.). На момент виписки зі стаціонару хворий почуває себе добре, задишка виникає при помірному або значному фізичному навантаженні.

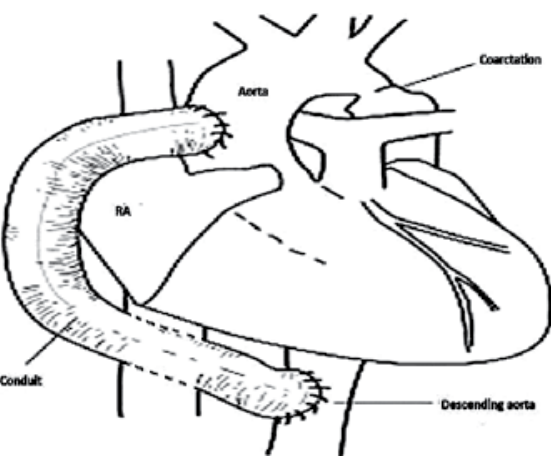

Рис. 4. Схема операиії

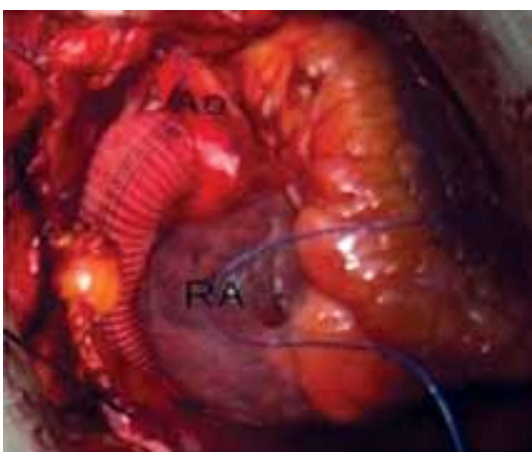

Рис. 5. Інтраопераційне фото проксимального анастомозу (вказано стрілкою)

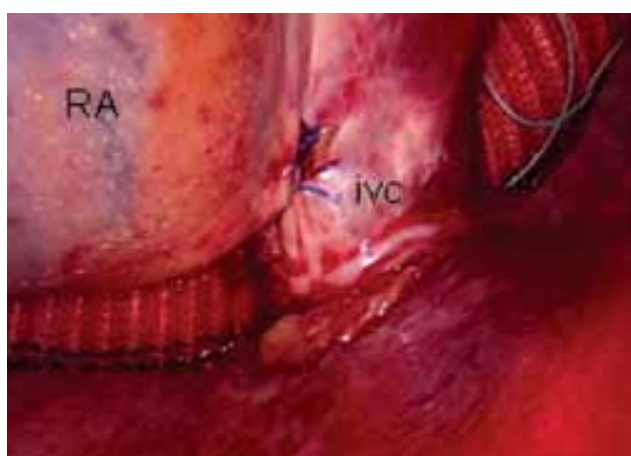

Рис. 6. Розташування кондуїту позаду нижньої порожнистої вени 


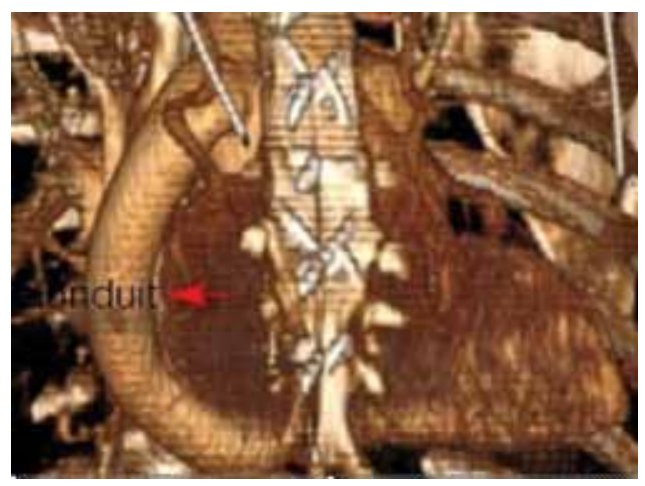

Рис. 7. КТ-ангіограма грудної порожнини з внутрішньовенним контрастуванням зображує анатомічне взаєморозташування кондуїту (вказано червоною стрілкою)

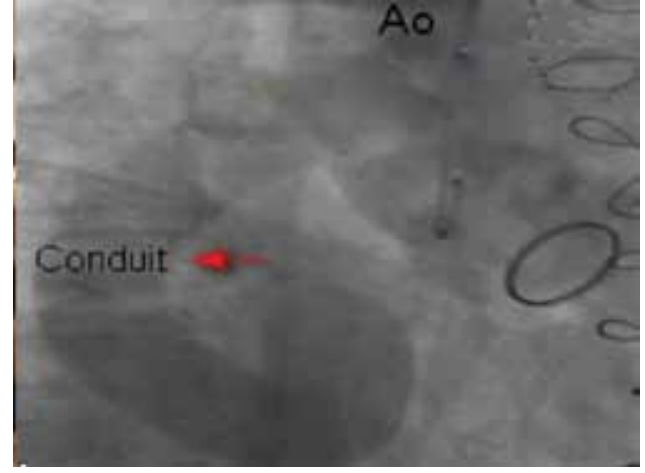

Рис. 8. Шунтограма зображує прохідність графта з хорошим кровотоком (вказано червоною стрілкою)
У післяопераційному періоді була виконана контрольна КТ-ангіографія з внутрішньовенним контрастуванням (рис. 7) та шунтографія (рис. 8).

Результати та обговорення. Незважаючи на велику кількість публікацій у закордонних джерелах, при огляді літератури не було знайдено жодного описаного випадку екстраанатомічного шунтування коарктації аорти з корекцією серцевої патології в дорослого пацієнта в Україні. Перша екстраанатомічна корекція коарктації аорти була виконана у 1975 році Dr. Edie [1]. Він сформував екстраанатомічний шунт із доступу серединної стернотомії і лівосторонньої торакотомії в один етап. Графт був проведений попереду воріт лівої легені і анастомозований із лівого латерального краю висхідної аорти. У 1977 p. Dr. Wukasch i Cooley вперше описали метод корекції коарктації аорти, екстраанатомічний шунт між висхідною і черевною аортою [1]. У 1980 p. Dr. Vijayanagar вперше описав процес формування шунта між висхідною і низхідною аортою лише із серединної стернотомії; графт був укладений уздовж лівого краю серця [2, 3]. А вже у 1983 p. Dr. Powell модифікував техніку Vijayanagar, за якої графт був спрямований позаду нижньої порожнистої вени і попереду правої нижньої легеневої вени [1]. Графт був анастомозований із висхідною аортою по боковій поверхні справа. Однією з переваг екстраанатомічного анастомозу є уникнення маніпуляції на коарктації аорти і колатеральних судинах, що значно зменшує вірогідність ішемічного ушкодження спинного мозку і знижує ризик фатальної кровотечі [2].

Згідно з даними зарубіжної літератури, вчасно не прооперована коарктація аорти закінчується летальним наслідком для $50 \%$ пацієнтів віком до 32 років і для 90\% пацієнтів віком до 58 років [7]. Анатомічна корекція є найбільш сприятливою для новонароджених і дітей. Потенційними ускладненнями хірургії $є$ крово- теча, ушкодження паренхіми легень, діафрагмального і блукаючого нерва, хілоторакс, ішемія спинного мозку [3]. Ризик ішемії спинного мозку після корекції коарктації аорти становить від 0,5\% до 5\% [3]. Основними показаннями до хірургічної корекції коарктації аорти з використанням техніки екстраанатомічного шунтування є коарктація або рекоарктація аорти в комплексі із серцевою патологією, що потребує корекції із серединної стернотомії; комплекс коарктація або рекоарктація аорти, за якої очікуються технічні труднощі при виборі методики прямої анатомічної корекції [4].

Отже, екстраанатомічний підхід $є$ найбільш прийнятним для дорослих пацієнтів у комплексі з патологією внутрішньосерцевих структур i/або коронарних артерій. Але постає питання про те, який підхід $є$ найбільш оптимальним. Двохетапна корекція передбачає дві різні хірургічні процедури: корекція коарктації з лівосторонньої торакотомії з подальшою корекцією серцевої патології із серединної стернотомії. Ця методика полегшує технічне виконання кожної з процедур, однак ризик операції і смертність значно зростають у випадку виникнення гемодинамічної нестабільності під час корекції коарктації аорти [2]. Також Двохетапний підхід пролонгує період перебування у стаціонарі і збільшує витрати на лікування. Одноетапна корекція коарктації аорти і серцевої патології виключає недоліки Двохетапної процедури, проте технічно є складнішою і пролонгує час роботи апарату штучного кровообігу [5].

Яку правильну тактику обрати для позиціонування екстраанатомічного графта? Можливі дві опції для формування дистального анастомозу: низхідна грудна або черевна аорта $[6,7]$. Кожен варіант має недоліки і переваги, показання і протипоказання. Розглянемо перший варіант. Дистальний анастомоз між низхідною аортою і судинним графтом є хорошою альтернативою, оскільки всі маніпуляції виконуються з одного доступу, що 
$€$ менш травматичним. Однак технічне виконання $є$ складнішим і має недоліки, а саме: візуалізація низхідної аорти і формування анастомозу, особливо в пацієнтів із бочкоподібною грудною кліткою та ожирінням, триваліший період роботи апарату штучного кровообігу, контроль гемостазу і потенційний ризик травми стравоходу з подальшими грізними наслідками інфекційних ускладнень [1]. Якщо ж розглядати варіант формування дистального анастомозу з черевною аортою, то можна дати такий коментар. Візуалізація і формування анастомозу не викликає технічних проблем, відсутня потреба в підключенні апарату штучного кровообігу, не становить особливих труднощів досягнення стабільного гемостазу [1]. Однак існують і недоліки цієї методики: кінкінг графта, інфекційні ускладнення, кишкова непрохідність, триваліший період перебування у стаціонарі і пролонговане реабілітаційне відновлення [4].

Беручи до уваги літературні дані, можна засвідчити, що анастомоз між висхідною і черевною аортою $є$ кращою альтернативою при бочкоподібній грудній клітці, повторній операції на серці, перикардіальному злуковому процесі [6]. Проте анастомоз між висхідною і низхідною грудною аортою має переваги у пацієнтів при попередній лапаротомії і злуковому процесі у черевній порожнині. 3 огляду на досвід іноземних фахівців, наш пацієнт мав протипоказання до екстраанатомічного анастомозу із серединної стернотомії у зв'язку зі своєю конституційною особливістю - бочкоподібною грудною кліткою [1]. Однак використання міні-інвазивного інструментарію дало можливість успішно виконати операцію і скоротити тривалість формування дистального анастомозу. На нашу думку, обрана тактика була більш оптимальною для пацієнта. Результати ретроспективного огляду свідчать, що екстраанатомічне шунтування коарктації аорти забезпечує задовільні клінічні результати $[1,2,5]$. Втім, існує універсального методу лікування, оскільки кожен окремий пацієнт є індивідуумом із власним анамнезом, конституцією і анатомією; крім того, слід уникати описаної методики для пацієнтів молодого віку у зв'язку з ростом організму.

\section{Висновки}

1. Екстраанатомічне формування анастомозу при коарктації аорти в комплексі із серцевою патологією $€$ задовільним альтернативним методом лікування для дорослої когорти пацієнтів.

2. Симультанна корекція коарктації аорти і серцевої патології є технічно складнішою, ніж двохетапна, але забезпечує менші витрати на лікування і скорочує реабілітаційний період.

3. Хоча й існують певні алгоритми в лікуванні даної групи пацієнтів, проте кожен випадок потребує індивідуального підходу.

\section{Література}

1. Heinemann MK, Ziemer G, Wahlers T, KohlerA, Borst HG. Extraanatomic thoracic aortic bypass grafts: indications, techniques, and results. Eur J CardiothoracSurg. 1997; 11:169-75.

2. MertYilmaz, BulentPolat, Davit Saba. Single-stage repair of adult aortic coarctation and concomitant cardiovascular pathologies: a new alternative surgical approach. Journal of Cardiothoracic Surgery. 2006; 1(18): 8-13.

3. Askin Ali Korkmaz,MustafaGuden, BurakOnan. New Technique for Single-Staged Repair of Aortic Coarctation and Coexisting Cardiac Disorder.Texas Heart Institute Journal. 2011;38 (4): 404-8.

4. Said SM, Burkhart HM, Dearani JA, Connolly HM, Schaff HV. Ascending-to- descending aortic bypass: a simple solution to a complex problem. Ann ThoracSurg. 2014; 97(6):2041-7.

5. Raina T, Rathnakar R, Aqarwal S. Extra Anatomic Bypass of Coarctation of the Aorta in an Adolescent: Avoiding Spinal Cord Ischemia. Journal of Medical Science. 2015; $1: 31-3$.

6. Eva Maria Delmo Walter, Mariano Francisco del Maria Javier and Roland Hetzer. Extra-anatomical bypass in complex and recurrent aortic coarctation andhypoplastic arch. Interactive CardioVascular and Thoracic Surgery Journal. 2017; 25: 400-6.

7. Luyao Ma, QunGu, Buqing Ni. Simultaneously surgical management of adult complex coarctation of aorta concomitant with intracardiac abnormality. Journal of Thoracic Disease. 2018; 10:5842-9.

\title{
Simultaneous correction of aortic coarctation and bicuspid aortic valve in an adult patient (case report)
}

\author{
Varbanets S. V., PukasA. Y., Furman M. M. \\ Ukrainian Children's Cardiac Center, Kyiv
}

Aortic coarctation is one of the most frequent congenital heart defects; the frequency is in the range of 6-7\%. Aortic coarctation is often associated with other heart defects, namely: a bicuspid aortic valve, an interventricular septal defect, and others. Purpose: to highlight our first experience of one-stage surgical correction of aortic coarctation and aortic valve pathology. Material and method. A 56-year-old man was hospitalized in the department in a planned manner with symptoms of chronic heart failure. Upon admission, the main complaints were shortness of breath with minimal physical stress and increased blood pressure. Aortic coarctation was diagnosed accidentally during coronary angiography in another medical 
institution. The thoracic aortic CT angiography with intravenous contrast diagnosed: sharp narrowing of the aorta in a typical place. Results and discussion. Despite a large number of publications in foreign sources, the literature review showed no cases of extra-anatomic bypass surgery of aortic coarctation with correction of a cardiac pathology in adult patients in the territory of Ukraine. The main indications for surgical correction of aortic coarctation using the technique of extraanatomic bypass surgery include: aortic coarctation or re-coarctation in combination with a cardiac pathology requiring correction via median sternotomy; complex aortic coarctation or re-coarctation associated with technical difficulties upon choosing the method of direct anatomical correction. Based on the experience of foreign institutions, our patient had contraindications to extra-anatomic anastomosis via median sternotomy due to a constitutional peculiarity, namely a barrel chest. However, the minimally invasive surgical instruments made it possible to perform the operation successfully with reduced time required for distal anastomosis. Conclusion. Extra-anatomic creation of anastomosis in aortic coarctation in combination with a cardiac pathology is a good alternative of treatment for an adult cohort of patients.

Key words: aortic coarctation, extra-anatomic graft, methods of surgical correction. 